新たに九州, 北海道その他の地域に 支部の設置をはかる.

\section{4. 昭和32年慶収支予算案}

昭和 32 年度収支予算書（案）

(32. 4. 1 33. 3. 31)

\begin{tabular}{|c|c|c|c|}
\hline 藏入 & の 部 & 墄 出 & の 部 \\
\hline 科 目 & 金 額 & 料 貝 & 金 額 \\
\hline 第一基本財 & 6,000 & 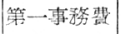 & 652,000 \\
\hline 産収入 & & 1.給 & 264,000 \\
\hline 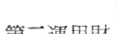 & & 2. 諸 給 & 127,000 \\
\hline 産収入 & 6,000 & 3. 備品费 & 17,000 \\
\hline & & 4. 消耗 费 & 94,000 \\
\hline 第三会 费 & $2,762,000$ & 5.会議翼 & 110,000 \\
\hline & & 6.雑 絮 & 40,000 \\
\hline 第四雑収入 & 76,000 & 第二事㷛㽞 & $2,111,000$ \\
\hline 第五前年度 & & 1. 矿究 费 & 180,000 \\
\hline 繰越金 & 205,000 & 2.普及輁 & 45,000 \\
\hline & & 3. 檠誌刊行 & $1,786,000$ \\
\hline & & 4 名費 & 100,000 \\
\hline & & 第三支部整 & 90,000 \\
\hline & & 第四予棤费 & 102,795 \\
\hline & & $\begin{array}{l}\text { 第五次期繰 } \\
\text { 越金 }\end{array}$ & 100,000 \\
\hline 合 計 & $3,055,795$ & 合 訫 & $3,055,795$ \\
\hline
\end{tabular}

\section{5. 昭和32年度役員および評 議員の選出}

昭和 32 年度役員㧤よび評議員の 選举に拈いて, 正会員の投票の結果,
会長はじめ 18 名の新役員および評 議員が下表のごとく決定した。

昭和 32 年度の理事会㧍よぴ評議 員会は，本総会に打いて選出された 18 名と前年度よりの留任者 16 名沶 よび会長選任の評議員 5 名により構 成される。な拈第 1 第 5 号議案は 異議なく原案どおり可決した。

\section{6. 名誉会員の推嘘}

本学会の前身であるテレビジョン 同好会の会長として多年にわたり我 が国テレビジョン技術の確立拈よび 向上に尽力された高柳健次郎先生， 执よび本学会の創立にあたり初代会 長として学会の今日を築き上げた丹 羽保次郎先生老, 定款第 6 条第 4 号 により本総会の議決により名誉会員 に推萀することを満場一致可決した。

\section{総会学術講演会}

5 月 18 日，第 3 回通常総会終了 後下記の通り学術講演会を開催した。

(1)テレビジョン受像機のトランジ スタ一化, 沼口安隆君 (NHK 技研)

(2)テレビジョン共同受像方式につ いて; 阿部正英君 (東芝)，久野古

\begin{tabular}{|c|c|c|c|c|c|c|c|c|c|}
\hline 役 名 & 氏 & 名 & 勤 務 先 & 任期 & 役 名 & 氏 & 名 & 勤 務 先 & 任期 \\
\hline 会 & 星合 & 正治 & 東京大学 & 1年 & 評議員 & 黒岩 & 現 & 日本ピクター & 2年 \\
\hline 副会長 & 三熊 & 文雄 & 日本放送協会 & 2年 & " & 五島队 & 8午郎 & 日本放送協会 & 2年 \\
\hline 庶務理事 & 松山幸 & 八郎 & 日本放送協会 & 2 年 & " & 城見多 & 津一 & 日本放送協会 & 2年 \\
\hline 会計理事 & 西尾 & 秀斑 & 日本電気 & 2 年 & $" \prime$ & 敛木 & 桂二 & 日本放送協会 & 2 年 \\
\hline & 森本 & 重武 & 電波監理局 & 2 年 & $" 1$ & 高木 & 昇 & 東京大学 & 1年 \\
\hline 評議 晨 & 浅見 & 義弘 & 北海道大学 & 2 年 & " & 高村 & 悟 & 日本倣送勃会 & 2年 \\
\hline$"$ & 岩片 & 秀雄 & 早稲田大学 & 1年 & " & 田辺 & 塪敏 & 日本放送楞会 & 2年 \\
\hline " & 遠藤 & 幸吉 & ラジオ東京 & 2年 & " & 野村 & 達治 & 日本放送茄会 & 2年 \\
\hline " & 金原 & 淳 & 名古屋大学 & 1年 & $"$ & 坛田 & 友義 & 早稲田大学 & 2年 \\
\hline
\end{tabular}

表紙 写真 説 明

写真はラジオ東京ス名ジオ番組の 一風景である。番組としては簡単な ものに属するが，それだけにカメラ

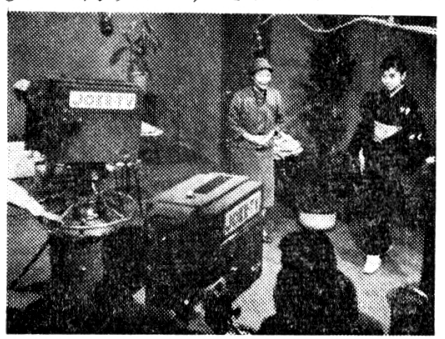

の構図等を特に留意しなければなら ない，使用カメラは 2 台乃至 3 台が 普通であり, 調整室内でスイッチャ 一が適当にカメラを切換えて番組の 進行を行 5. 出演者はカメラの上部 に赤ランプが点火することにより， 何れのカメラが働作しているか子知 る。な扔写真に見られるように $\mathrm{T}$ V では出演者の移動に従って音声をひ ろらため, 特殊のブームマイクを使 用している。(ラジオ東京提供)
夫君(松下電器)，坂野昌男君(ビク ター，高木俊讋君（コロムピア）

\section{分編 集 後記出}

森脇新編集長の構想である編集幹 事老置々制度も，上５やく幹事４⿱氏丶 が内定し，末た任期満了の編集委員 の交代为行わ机る等，編集委員会为 新風老吹き边久面目索刷新した。

わが国のテレビジョンの発展を反 映してか春の電気 4 学会連合大会は テレビ部門だけで実に 24 の研究論 文が発表された。まことに御同慶に たえない次第で岕る。そこで今月号 は読者の要望によりこれらの研究中 より数編の論文を選んで掲載した。 今後もどしどし揭載して行きたいと 思っている。

海外文献の紹介については今まで 十束委員が一人で苦学を重叔ながら 調査して米ら机たが，新しく山宮委 員が加わり, また近く小委員会も出 来る予定であるので一層充実したも のとなろら。また海外文献は抄訳と してかなりくわしく説明した方がよ いか, 或は内容紹介程度として数多 く揭载した方がいいか，等で今まで ことあるごとに編集委員会で論議さ れてきたが結論に至らず今日に及ん でいる，会員諸氏の御意見，御希望 を伺わせて戴けたら幸甚です(内野)

訂正 6 月号「䤅文・解説」閫㧍よび「新型 TV受像機」㯗に誤まりがありましたので下 記のごとく訂正します。

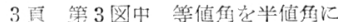

22 月の図中第 4 図の図面は第 3 図人，第 5 四の図面は第4图へ, 第 3 図の図面は第 5 図人をれを゙れ人れ換点すす

\begin{tabular}{|c|c|}
\hline 事務所 & 社用 テレビジョン学会 \\
\hline 部 & 東京都港区青山北町 $4-1$ \\
\hline & 電 波技術坫 会 内 \\
\hline & 振替口座 東京 174482 \\
\hline 関西卖部 & 大阪市東区䭴埸时6-4 \\
\hline & $\begin{array}{r}\text { NHK 大阪 中央放送局 技術部 内 } \\
\text { Tel. 東 }(94) 431 \sim 35\end{array}$ \\
\hline 東海支部 & 名古屋市東区久屋町 $7-10$ \\
\hline & $\begin{array}{r}\text { NHK 名古屋中央放送局技術部内 } \\
\text { Tel. 名古屋 (9) } 5551\end{array}$ \\
\hline
\end{tabular}

